УДК 636.8:636.7:619:616.36:619:616.6

Локес П. І., Кравченко С. О., Грищук А. В., кандидати ветеринарних наук

Полтавська державна аграрна академія

Локес-Крупка Т. П., аспірант

(науковий керівник - доктор біологічних наук, професор, академік НААН М. І. Цвіліховський)

Національний університет біоресурсів і природокористування України

\title{
МОРФОЛОГІЯ ПЕЧІНКИ ТА НИРОК ЗА ПЕЧІНКОВО-НИРКОВОГО СИНДРОМУ У СОБАК І КОТІВ
}

\section{Рецензент - доктор ветеринарних наук, професор Б. П. Киричко}

\begin{abstract}
Дослідженнями встановлено, щео за розвитку печінково-ниркового синдрому у собак та свійських котів y печіниі й нирках відбуваються структурні зміни. Патологоанатомічні зміни полягають у збільшенні, набряку та осередкових змінах кольору печінки $і$ нирок. Мікроскопічні зміни полягають у розвитку білкової (зернистої та гідропічної) дистрофії, осередковому некрозі гепатоцитів і проявах екстракапілярного гломерулонефриту й інтерстиційного нефриту, атрофії більшості звивистих канальців $i$ ниркових клубочків.
\end{abstract}

Ключові слова: собаки, коти, морфологія, нирки, печінка, печінково-нирковий синдром.

Постановка проблеми. Захворювання печінки та нирок запального і дистрофічного характеру у собак і свійських котів становлять значну частину внутрішньої незаразної патології тварин цих видів $[1,3,12]$. Проблема полягає у тому, що хвороби печінки нерідко ускладнюються функціональною недостатністю нирок, що призводить до поєднаного перебігу патології цих органів, ускладнює встановлення діагнозу та вибір напряму лікування. Клінічні симптоми у таких випадках дають недостатньо інформації для аналізу, тому необхідним є застосування додаткових методів досліджень, зокрема ультрасонографії, лабораторних дослідженнь крові та сечі. Між тим, розкриття окремих патогенетичних ланок патологічного процесу виглядає неможливим без дослідження структурних змін печінки та нирок у стані поєднаної патології $[7,8]$.

Виходячи 3 вищезазначеного, вивчення морфологічних змін печінки та нирок за печінковониркового синдрому в собак і котів наразі залишається актуальним.

Аналіз основних досліджень і публікацій, у яких започатковано розв'язання проблеми. Печінково-нирковий синдром - сумісна патологія печінки і нирок. У собак, котів та тварин інших видів можуть поєднуватися гепатит і гломерулонефрит, гепатит і пієлонефрит, гепатодист- рофія і гломерулонефрит, гепатодистрофія й пієлонефрит та інші види поліморбідності $[2,4,5$, 11]. У спеціальній літературі нині зустрічаються публікації, присвячені вивченню патоморфології печінки та нирок тварин різних видів за окремих патологій, таких як гепатит, гепатодистрофія [10], гломерулонефрит, пієлонефрит, синдром ниркової недостатності [9]. Проте морфологія печінки та нирок за печінково-ниркового синдрому у собак і свійських котів досі залишається невисвітленою. Тому спеціальні дослідження у даному науковому напрямі $є$ вкрай необхідними.

Мета і завдання дослідження. Мета дослідження - вивчення морфологічних змін печінки та нирок собак і котів за печінково-ниркового синдрому.

Основним завданням було вивчення мікроскопічних змін клітин печінки та нирок за вказаної патології.

Матеріали і методи. Дослідження проводили в умовах кафедри терапії Полтавської державної аграрної академії. У випадках загибелі собак та котів із діагнозом «печінково-нирковий синдром» вивчали патологоанатомічні зміни та проводили відбір матеріалу для наступних гістологічних досліджень.

Шматочки печінки і нирок досліджених тварин розміром $1 \times 1 \times 1$ см фіксували $10 \%$ нейтральним розчином формаліну впродовж однієїдвох діб, після чого зневоднювали у спиртах зростаючої концентрації (від 500 до абсолютного). Отримані зразки після фіксації та зневоднення заливали в парафін за класичною методикою [6]. 3 отриманих блоків за допомогою санного мікротома виготовляли серійні зрізи товщиною 7,5 мкм i фарбували гематоксилінеозином та стабілізували у полістиролі. Характерні патогістологічні зміни в гістопрепаратах фотографували на мікроскопі МБІ-3 3 мікрофотонасадкою МФН-12.

Матеріалом для досліджень стали собаки та коти, які загинули внаслідок печінково- 


\section{ВЕТЕРИНАРНА МЕДИЦИНА}

ниркового синдрому, діагностованого на основі клінічних і біохімічних досліджень.

У ході виконання роботи використано матеріал, відібраний від трупів трьох собак та чотирьох котів.

Результати досліджень. У всіх тварин виявляли виразні морфологічні зміни як у печінці, так і в нирках. На поверхні печінки знаходили ділянки світло-сірого та сіро-коричневого кольору різних розмірів і форми. На розрізі малюнок був згладжений, поверхня розрізу - тьмяна.

У процесі гістологічних досліджень реєстрували зміни гепатоцитів. Клітини були нерівномірно збільшені, цитоплазма їх набрякла, каламутна, нерівномірно забарвлена, $з$ дрібними ацидофільними білковими зернами. Межі клітин та їх ядра важко диференціювалися або ж були й зовсім непомітні: такі зміни притаманні зернистій дистрофії. Крім того у трьох препаратах спостерігали розширення просвітів синусоїдних гемокапілярів та жовчних капілярів (рис. 1).

Між часточками спостерігали розростання волокнистої сполучної тканини, що було найвиразнішим у ділянці печінкових тріад. Місцями невеликі осередки розростання волокнистої сполучної тканини реєстрували і всередині часточок. Проте тут такі розростання знаходилися на поча- тковій стадії, поскільки були представлені невеликими групами фібробластів та фіброцитів, навколо яких виявляли лише окремі колагенові волокна.

У печінці двох тварин окрім зернистої дистрофії спостерігали ознаки гідропічної дистрофії 3 вакуолізацією цитоплазми та ядер гепатоцитів, дрібні осередки некрозу. У ділянках некрозу групи гепатоцитів (2-4) мали вигляд безформених рожевих конгломератів, що містили залишки зруйнованих ядер. На окремих ділянках часточок реєстрували групи гепатоцитів (3-5) у стані паранекрозу (рис. 2).

Такі клітини були збільшені в об'ємі, контури ледь виражені, цитоплазма мала інтенсивнорожеве забарвлення, в ядрах - ознаки рексису. У більшості випадків спостерігали надмірне кровонаповнення центральної вени часточок та вени тріади міжчасточкової сполучної тканини, помірно виражений набряк периваскулярної тканини.

Нирки були збільшені й набряклі, колір поверхні - нерівномірний. До того ж світліші ділянки (без будь-якої закономірності) чергувалися 3 ділянками синюшного кольору. Консистенція нирок також була неоднорідною. Пальпували ділянки більш щільної, ніж у нормі, консистенції.

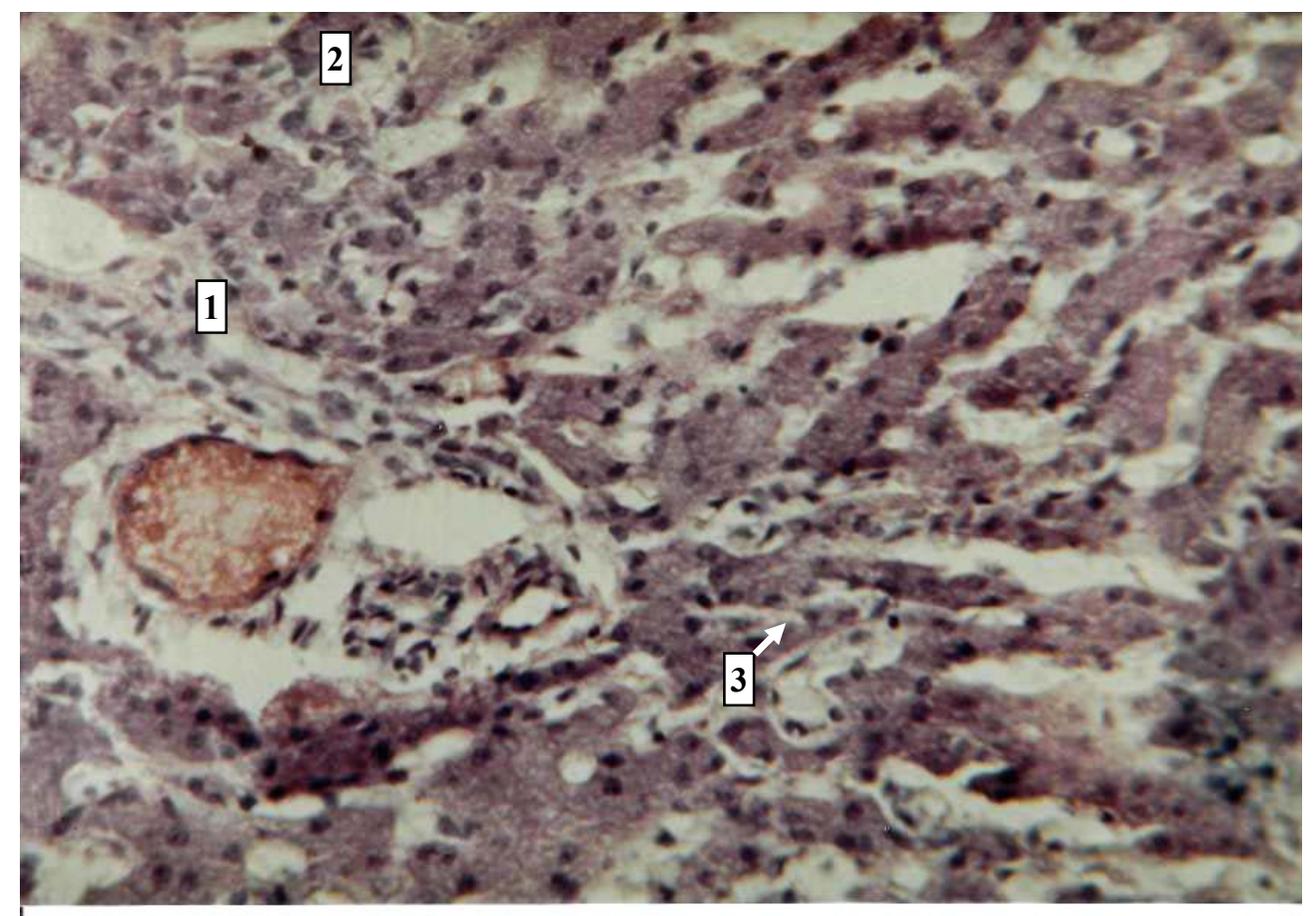

Рис. 1. Мікроскопічна будова печінки собаки віком 3 роки:

1 - розростання волокнистої сполучної тканини в ділянці печінкової тріади; 2 - розростання волокнистої сполучної тканини всередині печінкової часточки; 3 - розщирення просвітів синусоїдних капілярів та жовчних щзілин. Забарвлення гематоксиліном Караці та еозином. $3 б . ~ \times 200$. 


\section{ВЕТЕРИНАРНА МЕДИЦИНА}

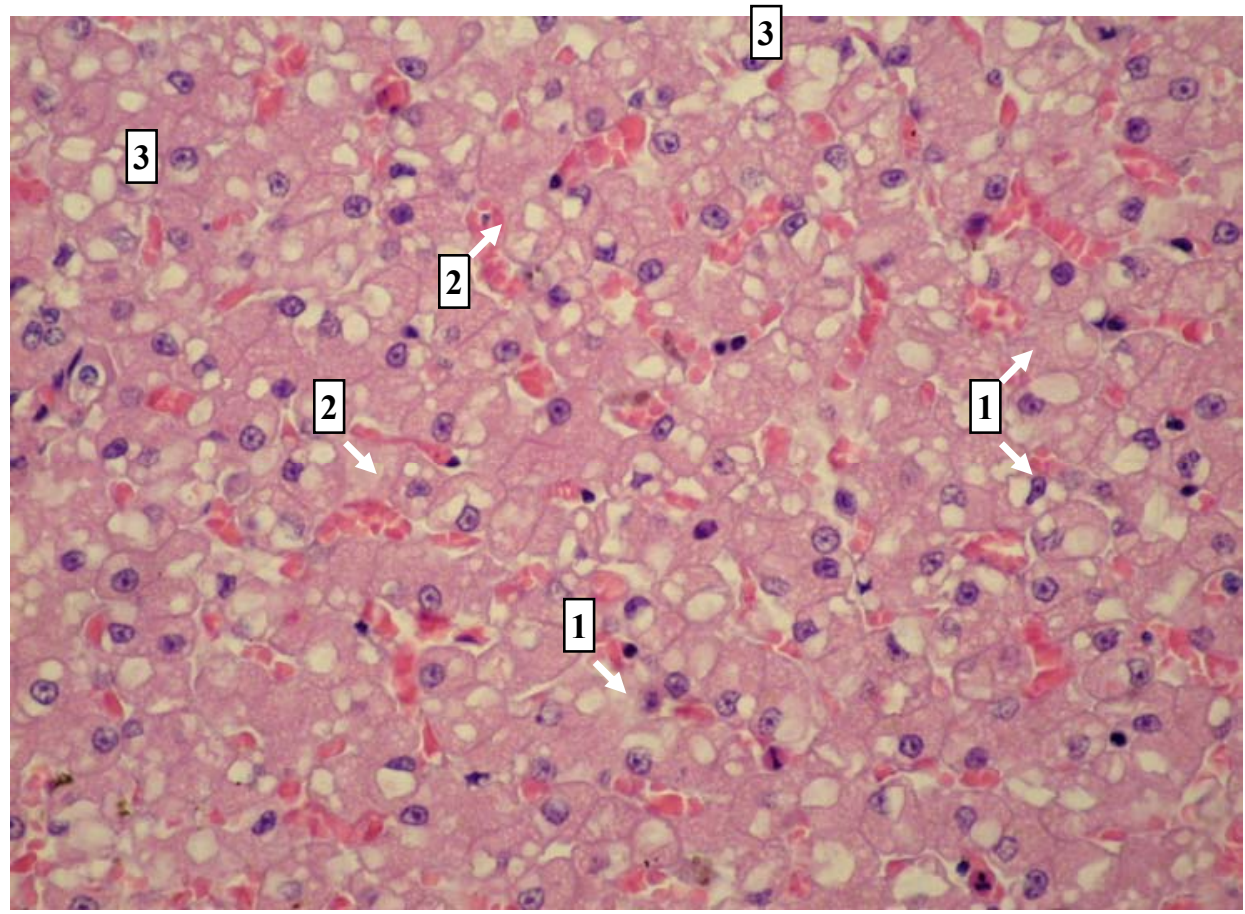

Рис. 2. Гістологічний препарат печінки кота віком 1 рік:

1- гепаточити з ознаками гідропічної дистрофії та вакуолізаџї циитоплазми; 2 - підвищене кровонаповнення капілярних сунусоїдів; 3 - паранекроз гепатоцитів. Забарвлення гематоксиліном Караиі та еозином. 3б. × 400.

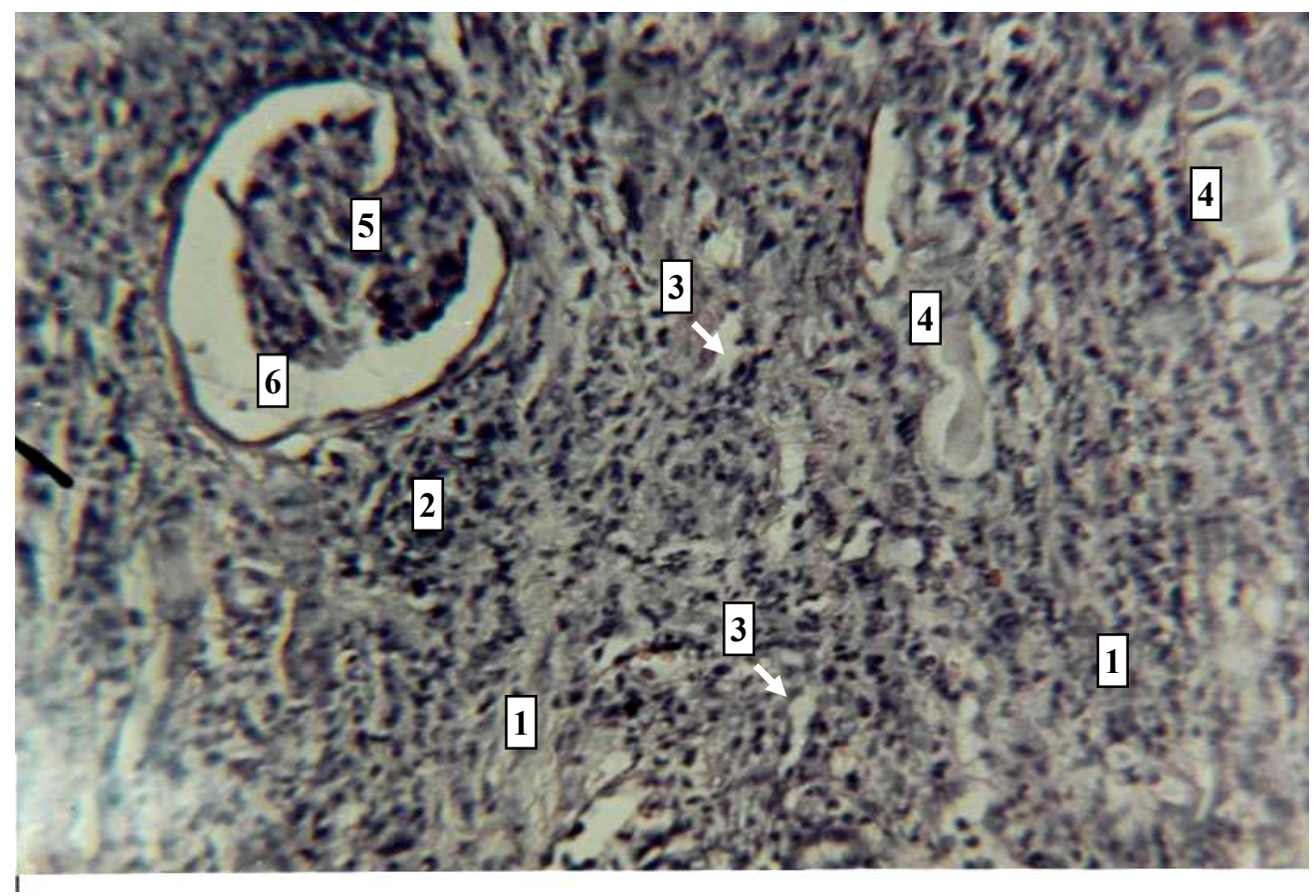

Рис. 3. Мікроскопічна будова кіркової зони нирки за печінково-ниркового синдрому собаки віком 3 роки:

1 - розростання щільної волокнистої сполучної тканини; 2 -запальна інфільтрація; 3 -звуження просвітів звивистих канальщів; 4 - розиирення просвітів звивистих канальців; 5 -атрофоване ниркове тільце; 6 - серозний ексудат у просвіті капсули Шумлянського-Боумена. Забарвлення гематоксиліном Караці та еозином. 3б. × 200. 


\section{ВЕТЕРИНАРНА МЕДИЦИНА}

На розрізі межа між кірковою та мозковою речовинами була згладжена чи взагалі не диференціювалася. Ділянки щільнішої консистенції мали світле, сіро-біле забарвлення.

У процесі проведення гістологічних досліджень у кірковій речовині нирок нами були знайдені чималі осередки розростання щільної волокнистої сполучної тканини, що супроводжувались атрофією більшості звивистих канальців та ниркових тілець. Окрім того спостерігали значне розширення просвітів окремих канальців 3 утворенням мікрокіст. Внаслідок руйнування нефроцитів у ділянках розширення стінка таких канальців складалася лише з базальної мембрани. Реєстрували ознаки як гострого, так і хронічного екстракапілярного гломерулонефриту, запальні інфільтрати навколо звивистих канальців (рис. 3).

Знаходили збільшені в об'ємі ниркові тільця 3 вакуолізацією ендотеліоцитів капілярного склепіння, $з$ накопиченням у порожнині капсули Боумена-Шумлянського серозного ексудату. У капілярному склепінні реєстрували розширення просвіту капілярів. На окремих ділянках кіркової зони внаслідок скупчення серозного ексудату в порожнині капсули відмічали зміщення дещо вбік ниркового тільця у просвіті капсули Шумлянського-Боумена. Частина подоцитів і нефроцитів перебували у стані зернистої та гідропічної дистрофії. Відмічали кровонаповнення судин між звивистими канальцями.

У трьох випадках - у ділянках із розростанням сполучної тканини в кірковій зоні нирок - внаслідок атрофії судинних клубочків просвіти капсули Шумлянського-Боумена були розширені й містили незначну кількість серозного ексудату (рис. 3).

У мозковій речовині, як і в кірковій, на значних ділянках спостерігали розростання щільної волокнистої сполучної тканини, яке призводило до атрофії значної частини прямих канальців. Канальці, що лишилися, були розтягнуті вмістом, внаслідок чого виглядали нерівномірно розширеними й набували неправильної форми (рис. 4). Їх епітелій частково руйнувався або злущувався у просвіт канальців. Епітеліоцити, які лишалися на базальній мембрані, знаходились у стані зернистої або гідропічної дистрофії.

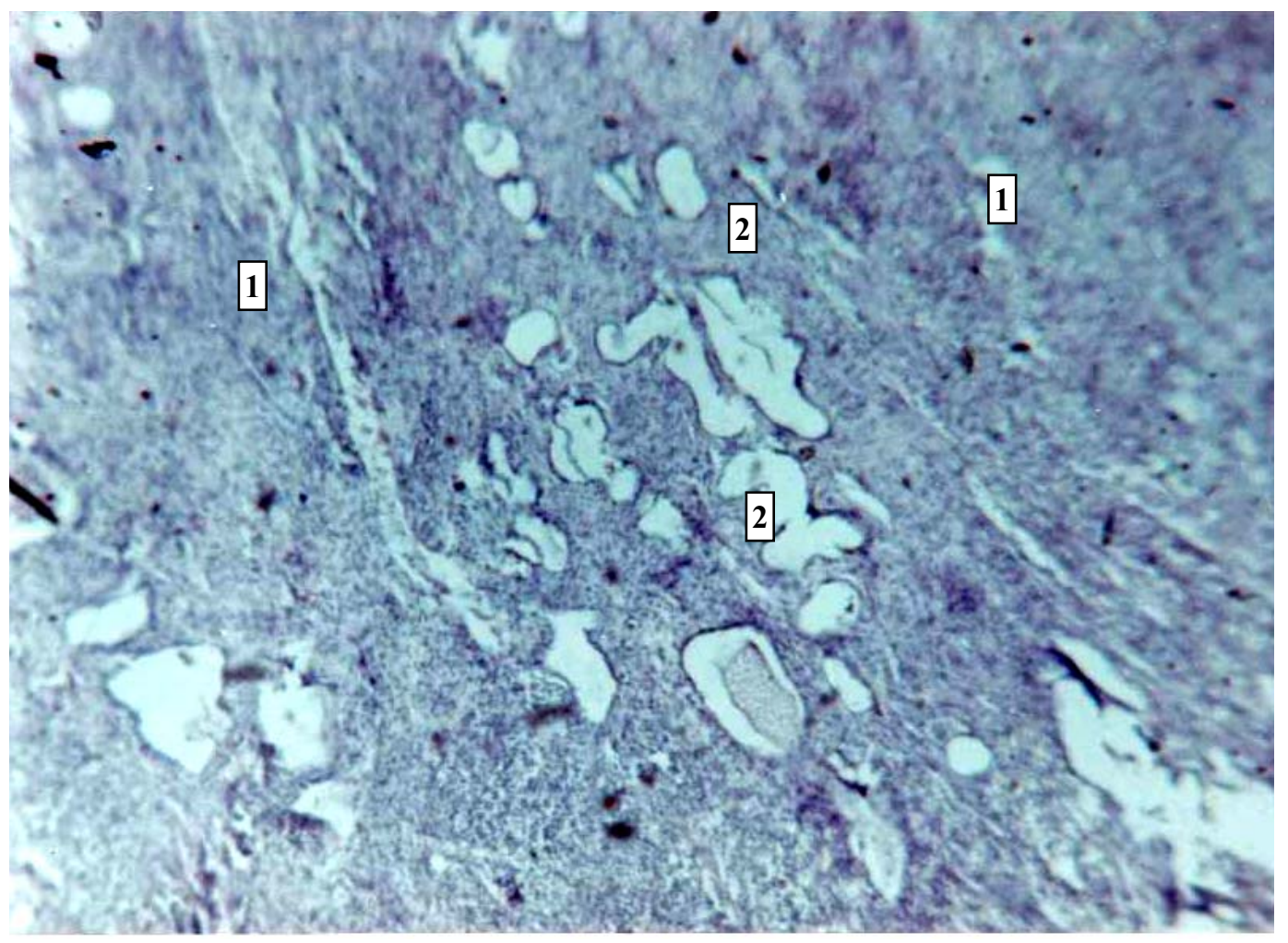

Рис. 4. Мікроскопічна будова мозкової зони нирки за печінково-ниркового синдрому собаки віком 3 роки:

1 - розростання щзільної волокнистої сполучної тканини в мозковому шарі; 2 - нерівномірно розтягнені вмістом прямі канальц̧і. Забарвлення гематоксиліном Караці та еозином. $3 б . \times 100$ 


\section{ВЕТЕРИНАРНА МЕДИЦИНА}

Таким чином, морфологічні зміни за печінково-ниркового синдрому в собак і котів характеризуються ураженням печінки у вигляді білкової (зернистої й гідропічної) дистрофії та утворенням дрібних осередків некрозу. Між часточками розростається волокниста сполучна тканина, найбільш виражена у ділянках печінкових тріад.

У нирках патологічний процес характеризується розвитком екстракапілярного гломерулонефриту, склеротичними змінами та явищами хронічного інстерстиційного нефриту.

Розростання сполучної тканини призводить до

\section{БІБЛІОГРАФІЯ}

1. Болезни печени и желчевыводящих путей: Руководство для врачей / Под ред. В. Т. Ивашкина. - М. : Издатдом «М-Вести», 2002. - 416 с.

2. Болезни собак и кошек. Комплексная диагностика и терапия болезней собак и кошек: учеб. пособие / [Т. К. Донская Г. Г. Щербаков, Г. В. Полушин]; под ред. С. В. Старченкова. - С.-Пб. : Спец. литература, 2006. - 655 с.

3. Внутрішні хвороби тварин / [В. І. Левченко, І. П. Кондрахін, В.В. Влізло [та ін.]; за ред. В. І. Левченка. - Біла Церква, 2012. - Ч. 1. - 528 с.

4. Головаха B. I. Гепато-ренальний синдром у службових собак / В. І. Головаха, О. А. Дикий // Наукові досягнення в галузі ветеринарної медицини: Матеріали Міжнародної науковопрактичної конференції молодих вчених (1-2 квітня). - Харків, 1997. - С. 17-18.

5. Інформативність окремих показників для діагностики патології печінки і нирок у собак / О. А. Дикий, В. І. Головаха, В. П. Фасоля [та ін.] // Вісник Білоцерківського державного аграрного університету. - Біла Церква, 2000. - Вип. 11. C. 32-37.

6. Меркулов А.Б. Курс патогистологической техники / А. Б. Меркулов. - Л. : Медицина, 1969. звуження й повного закриття просвіту канальців нирок. Розширення просвітів окремих канальців, 3 одного боку, можна віднести до компенсаторних процесів ураженого органа, a, 3 іншого, це створює передумови для переродження таких ділянок.

Висновок. За поєднаної патології печінки й нирок (печінково-ниркового синдрому) у собак i котів відбуваються зміни морфології печінки та нирок, що полягають у розвитку білкової дистрофії, осередків некрозу, екстракапілярного гломерулонефриту та інтерстиційного нефриту.

$-237 \mathrm{c}$.

7. Морозенко Д. В. Інформативність клініколабораторних та інструментальних досліджень у діагностиці патології нирок у домашніх котів / Д. В. Морозенко, М. І. Карташов, А. М. Закревський // Вісник Білоцерківського державного аграрного університету: зб. наук. праць. - Біла Церква, 2006. - Вип. 40. - С. 138-146.

8. Нефрология и урология собак и кошек / Пер. с англ. Е. Махиянова. - М. : Аквариум ЛТД, 2003. $-272 \mathrm{c}$.

9. Ниманд X. Г. Болезни собак / Х. Г. Ниманд, П. Б. Сутер : пер. с англ. - М. : Аквариум ЛТД, 2001. - C. 604-608.

10. Уиа Б. В. Болезни печени собак / Б. В. Уша, И. П. Беляков. - М. : ПАЛЬМАпресс, 2002. - 36 с.

11. Фасоля В. П. Діагностика і лікування гепато-ренального синдрому у собак службових порід / В. П. Фасоля // Білоцерківського державного аграрного університету: зб. наук. праць. - Біла Церква, 2008. - Вип. 51. - С. 102-107.

12. Чандлер E. A. Болезни кошек / Е. А. Чандлер, К. Дж. Гаскелл, Р. М. Гаскел: пер. с англ. М. : Аквариум, $2002-696$ с. 